\title{
Electrically switchable nanolever technology for the screening of metal-chelating peptides in hydrolysates
}

Sarah EL HAJJ ${ }^{1,7^{*}}$, Cindy Tatiana SEPÚLVEDA RINCÓN ${ }^{1,2}$, Jean-Michel GIRARDET ${ }^{3}$, Céline CAKIR-KIEFER ${ }^{4}$, Loic STEFAN ${ }^{5}$, José Edgar ZAPATA MONTOYA², Sandrine BOSCHI-MULLER ${ }^{6}$, Caroline GAUCHER ${ }^{7}$, and Laetitia CANABADY-ROCHELLE ${ }^{{ }^{*}}$

${ }^{1}$ Université de Lorraine, CNRS, LRGP, F-54000 Nancy, France

2Universidad de Antioquia, Nutrition \& Food Technology Group, 050010 Medellín, Colombia

${ }^{3}$ Université de Lorraine, INRAE, IAM, F-54506 Vandœuvre-lès-Nancy, France

${ }^{4}$ Université de Lorraine, INRAE, URAFPA F-54505 Vandœuvre-lès-Nancy, France

${ }^{5}$ Université de Lorraine, CNRS, LCPM, F-54000 Nancy, France.

6Université de Lorraine, CNRS, IMoPA, F-54505 Vandoeuvre Les Nancy, France.

${ }^{7}$ Université de Lorraine, CITHEFOR, F-54505 Vandoeuvre Les Nancy, France

*Corresponding authors:

E-mail: laetitia.canabady-rochelle@univ-lorraine.fr

Telephone number: $+33(0) 3.72 .74 .38 .86$. 
Abstract. Metal-chelating peptides (MCP), are considered as indirect antioxidants due to their capacity to inhibit radical chain reaction and oxidation. Here, we propose a new proofof-concept for the screening of MCPs present in protein hydrolysates for valorizing their antioxidant properties by using emerging time-resolved molecular dynamics technology, switchSENSE ${ }^{\circledR}$. This method unveils possible interactions between MCPs and immobilized nickel ions using fluorescence and electro-switchable DNA chip. The switchSENSE ${ }^{\circledR}$ method was first set up on synthetic peptides known for their metalchelating properties. Then, it was applied to soy and tilapia viscera protein hydrolysates. Their $\mathrm{Cu}^{2+}$-chelation capacity was, in addition, determined by UV-visible spectrophotometry as a reference method. The switchSENSE ${ }^{\circledR}$ method has displayed a high sensitivity to evidence the presence of MCPs in both hydrolysates. Hence, we demonstrate for the first time that this newly introduced technology is a convenient methodology to screen protein hydrolysates in order to determine the presence of MCPs before launching time-consuming separations.

Key words: electro-switchable chip, metal-chelating peptide, hydrolysate, soy protein, tilapia protein. 


\section{Introduction}

Nowadays, biomolecules are gaining attention as alternatives to chemicals in various industrial applications such as nutrition, cosmetics, and pharmaceutics. Bioactive peptides with biological activities (e.g., antioxidant, antihypertensive, anticancer activity) ${ }^{1}$ based on their amino acid composition and their primary sequence, have been produced by enzymatic hydrolysis. ${ }^{2}$ Metal ion chelation is a functional property commonly investigated in literature..$^{3,4}$ Indeed, metals ions such as iron, zinc, calcium and copper are essential for several biological functions such as enzyme catalysis, oxygen transport, and neurotransmitter release. ${ }^{5}$ However, their bioavailability is poor due to their low solubility in human fluids. ${ }^{6}$ Metal-chelating peptides (MCPs) contribute to minerals absorption and bioavailability, ${ }^{6}$ thus regulating ion concentrations through selective bindings. ${ }^{4}$ Finally, iron and copper-chelating peptides - while complexing these transient metal ions - can act as indirect antioxidants by inhibiting in vivo the Fenton and Haber-Weiss reactions responsible for the formation of reactive oxygen species (including the hydroxyl radical) and subsequent radical chain reactions.

Protein hydrolysates constitute interesting sources of metal-chelating peptides to explore. Among natural resources, hydrolysates produced from soy proteins, ${ }^{7}$ barley hordein, ${ }^{8}$ and milk whey, ${ }^{9}$ were reported to contain MCPs. In the present study, two sources of potential MCPs were investigated: a tilapia by-product and soy protein isolate. Tilapia is one of the species with the highest aquaculture production in the world, and represents $10 \%$ of all finfish species. ${ }^{10}$ Yet, by-products generated by its aquaculture production are about $60 \%$ of the animal total weight. ${ }^{11}$ Enzymatic hydrolysis of tilapia by-products is a convenient method to generate protein hydrolysates with high content of bioactive peptides. ${ }^{12-14}$ In 
the case of soy protein isolates, enzyme technology is often developed to unveil proteinencrypted bioactive sequences with potential health benefits (e.g., antioxidant activities), and to improve the techno-functional properties for instance..$^{15}$

To date, the selective separation of bioactive peptides from a hydrolysate is still studied empirically: peptides are separated into various fractions, each one being evaluated for its bioactivity up to isolate the target peptide and to identify its sequence by tandem mass spectrometry. For MCPs separation, immobilized metal ion affinity chromatography (IMAC) is a technique that takes advantage of the interaction between an immobilized metal ion and a protein or a peptide present in complex biological samples. IMAC can separate peptides or proteins efficiently ${ }^{16}$ and has been investigated for several years. ${ }^{17}$ Nevertheless, the IMAC phase has a moderate sensitivity, ${ }^{16}$ limited performance and flexibility, in addition to the waste of molecules of interest upon the washing up of the nonspecific binding molecules, ${ }^{18}$ which constitute main disadvantages of IMAC.

Hence, MCP screening in hydrolysates is a priority before launching time-consuming separation. Among various screening approaches, the differential analysis of mass spectra of hydrolysates was carried out in the presence and in the absence of metal ion using liquid chromatography coupled to high resolution mass spectrometry in order to detect iron(II)-chelating peptide in protein hydrolysates. ${ }^{19}$ In addition, Surface Plasmon Resonance (SPR) was reported to compare the affinity constant of different tagged proteins bound to metal ions ${ }^{20-22}$ or to study the affinity of His-tag peptides to $\mathrm{Ni}^{2+}$ ions. ${ }^{23}$ Recently, our team developed a strategy to screen MCPs using affinity constants determined in SPR ${ }^{24}$ and to simulate their IMAC separation. ${ }^{25}$ Like SPR, the newly introduced switchSENSE ${ }^{\circledR}$ technology allows to analyse biomolecular interactions in real time. The originality of this latter technology is based on the use of electro-switchable 
fluorescent DNA nanolevers in which one DNA strand bears a fluorophore while its complementary strand is functionalized by a capture molecule (i.e. complexing agent), itself coupled to a ligand (e.g., metal ion). ${ }^{26}$ Once the target MCP interacts with the metal ion immobilized on the complexing agent, the fluorescence is quenched and the alternating mobility of the DNA nanolevers is altered. These changes allow to determine kinetics and affinity constants in addition to other information related to the analyte (MCPs herein) such as structural and conformational characteristics. As immobilized metals, nickel ions are widely used for protein purification due to their affinity with the exposed side chains of histidine and cysteine in proteins. ${ }^{27}$ With six coordination sites, $\mathrm{Ni}^{2+}$ can strongly bind to a complexing agent such as the tetradentate nitrilotriacetic acid (NTA), while some sites still remain available to interact with the target peptide.$^{27}$

The aim of this study is to make a proof-of-concept for the screening of metal-chelation activity of peptides present in protein hydrolysates. To that purpose, the switchSENSE ${ }^{\circledR}$ methodology was first set up under static and dynamic modes with small synthetic MCPs, and then with protein hydrolysates, i.e. soy protein hydrolysate $(\mathrm{SPH})$ and Tilapia protein hydrolysate (TPH). Prior to that, the global capacity of protein hydrolysates to chelate nickel was checked by standard spectrometry methods.

\section{Material and Methods}

\section{Production of protein hydrolysates}

Soy protein hydrolysate. Soy protein isolate (kindly provided by SAS improve, Dury, France) was composed of $87 \%(\mathrm{w} / \mathrm{w})$ pure proteins. The soy protein isolate powder was dissolved in $50 \mathrm{mM}$ ammonium bicarbonate $(2 \% \mathrm{w} / \mathrm{v})$ and pre-heated at $90{ }^{\circ} \mathrm{C}$ for $5 \mathrm{~min}$. 
Indeed, this ammonium bicarbonate solution has a good buffering capacity in order to regulate well the $\mathrm{pH}$ of the medium according to the optimum activity of the enzymes. Besides, this solution does not contain ionic element that might interfere in metalchelation.

Alcalase ${ }^{\circledR}(\geq 2.4 \mathrm{U} / \mathrm{g})$, Protamex ${ }^{\circledR}(\geq 1.5 \mathrm{U} / \mathrm{g})$, or Flavourzyme ${ }^{\circledR}(\geq 500 \mathrm{U} / \mathrm{g})$, purchased from Sigma-Aldrich (St. Louis, MO, USA) were the proteolytic enzymes used. Hydrolysis was performed with Enzyme/ Substrate ratio equal to $1 \%(\mathrm{w} / \mathrm{w})$ for $1 \mathrm{~h}$ or $3 \mathrm{~h}$, in a beaker equipped with a thermostatic water jacket at the enzymes' optimal working temperature $\left(55^{\circ} \mathrm{C}\right.$ ) at pH 8.0 (with Alcalase ${ }^{\circledR}$ ) and $\mathrm{pH} 7.0$ (with Protamex $^{\circledR}$, or Flavourzyme ${ }^{\circledR}$ ). As described in Figure S1, enzymes were then inactivated at $100^{\circ} \mathrm{C}$ for 15 min by incubating in boiling water. Then, soy protein hydrolysates (SPHs) were cooled at room temperature, centrifuged (10,000 g, $15 \mathrm{~min})$, freeze-dried by lyophilization for 48 hours and stored at $20^{\circ} \mathrm{C}$ until used.

Tilapia viscera protein hydrolysate. Fresh red tilapia viscera (Oreochromis spp.; kindly provided by Piscícola El Gaitero Antioquia, Colombia) were minced immediately upon arrival using a blender (Black \& Decker, Hampstead, MD, USA). Hydrolysate preparation is schematized on Figure S2. Tilapia viscera were heated at $90^{\circ} \mathrm{C}$ for 20 min to inactivate endogenous enzymes. Upon heating, the fat melted and separated from other components of the viscera. Then, sample was frozen at $-20^{\circ} \mathrm{C}$ for $24 \mathrm{~h}$ to easily remove the solidified fat by phase separation. Viscera were then packed in PVC bags and stored at $-20{ }^{\circ} \mathrm{C}$ until further use. Enzymatic hydrolysis of tilapia viscera was carried out in a batch reactor Bioflo 310 (New Brunswick Scientific Co., Enfield, CT, USA) with pH and temperature maintained at 10 and $59 \stackrel{\circ}{\circ}$, respectively, through the automatic control of the Bioflo reactor $310 \AA$ (New Brunswick Scientific Co., Inc. USA). The reaction was 
started by the addition of Alcalase ${ }^{\circledR} 2.4 \mathrm{~L}$ (Novozymes, Copenhagen, Denmark) at enzyme/substrate mass ratio of $1: 10$. The hydrolysis was monitored by $\mathrm{pH}$-stat method for $3 \mathrm{~h}$. Once produced, the tilapia protein hydrolysate $(\mathrm{TPH})$ was freeze-dried and stored at $-20^{\circ} \mathrm{C}$ until use. Then, a purification step was carried out on Sep-Pak C18 cartridges (Waters Associates, Milford, MA, USA) to remove salts and other impurities. The cartridges were equilibrated with an aqueous eluent containing $1 \%(\mathrm{v} / \mathrm{v})$ acetonitrile and $0.01 \%(\mathrm{v} / \mathrm{v})$ trifluoroacetic acid. The TPH hydrolysate was solubilized at $10 \mathrm{mg} / \mathrm{mL}$ in the same equilibration eluent and loaded $(1 \mathrm{~mL})$ onto the cartridge. After loading, the cartridge was washed with the same eluent $(3 \mathrm{~mL})$, and TPH was then eluted with a mixture of $30 \%$ acetonitrile and $0.01 \%$ trifluoroacetic acid in water. The eluted desalted hydrolysate was then freeze-dried and stored at $-20^{\circ} \mathrm{C}$ until further analyses. ${ }^{28}$

\section{Peptide characterization}

Peptide concentration in hydrolysates (i.e., TPH and SPHs) was quantified using orthophthaldialdehyde-based assay (OPA; ThermoFisher Scientific, Loughborough, UK) in the presence of $N, N$-dimethyl-2-mercaptoethyl-ammonium (ThermoFisher). ${ }^{24,29}$ The results were expressed as $\mathrm{mM}$ equivalent (eq.) $\mathrm{NH}_{2}$ using a calibration curve performed with glycine (Table S1).

SPHs fractions were analyzed for size distribution by sodium dodecyl sulfate polyacrylamide gel electrophoresis (SDS-PAGE) 15\% (v/v) by comparison with molecular weight marker (Bio-Rad, Marnes La Coquette, France) according to the Laemmli method..$^{30}$ 
The molecular weight distribution of tilapia hydrolysate was determined by size-exclusion chromatography in a previous study that showed the presence of peptides below 6511 Da, with a striking amount around $336 \mathrm{Da}^{31}$

\section{Real-time switchSENSE ${ }^{\circledR}$ analysis}

Synthetic peptides (i.e. $\mathrm{HHHHHH}, \mathrm{HHH}, \mathrm{HGH}, \mathrm{HW}$, and $\beta A H$ also called carnosine; Sigma-Aldrich), able to bind nickel ions (see peptide chemical structures on Figure S3), $\mathrm{TPH}$, and SPH were prepared in $10 \mathrm{mM}$ Tris- $\mathrm{HCl}$ buffer, $\mathrm{pH}$ 7.4, containing $40 \mathrm{mM} \mathrm{NaCl}$, and $0.05 \%(\mathrm{v} / \mathrm{v})$ Tween 20 (buffer T40). The switchSENSE ${ }^{\circledR}$ experiments were carried out with a biosensor analyzer DRX (SwitchSENSE ${ }^{\circledR}$ Dynamic Biosensors GmbH, Planegg, Germany). An electro-switchable DNA chip MPC-48-2-R1-S containing tris-nitrilotriacetic acid and the fluorescent probe Cy5, was used according to the instructions supplied with the Tris-NTA kit of Dynamic Biosensors. The chip is composed by 6 electrodes connected to 2 spots used as references and 4 sample spots carrying the $\mathrm{Ni}^{2+}$ functionalized acid (NTA $)_{3}$ )-tagged DNA nanolevers. The principle of the switchSENSE ${ }^{\circledR}$ technology (Figure S4, panels A and B) is explained in details by Langer et al. ${ }^{26}$ Fluorescence static measurements (at $25^{\circ} \mathrm{C}$ ) were performed on one spot out of the 4 sample spots. Several concentrations of synthetic peptides $(0.5,1$ and $10 \mu \mathrm{M}), \mathrm{TPH}$ ( 5 and $10 \mu \mathrm{M}$ eq. $\left.\mathrm{NH}_{2}\right)$, and $\mathrm{SPH}\left(10,100\right.$, and $1000 \mu \mathrm{M}$ eq. $\left.\mathrm{NH}_{2}\right)$ were injected in the microfluidic device at a flow rate of $10 \mu \mathrm{L} \cdot \mathrm{min}^{-1}$ for $10 \mathrm{~min}$ (association phase). Then, buffer was injected at $30 \mu \mathrm{L} \cdot \mathrm{min}^{-1}$ for 120 min to release the analytes (dissociation phase). All over the kinetic experiments (static measurements), a blank control was performed with peptide-free buffer and subtracted to normalize the signal. 
Between the former association and dissociation phases, the flow was stopped, and dynamic measurements were performed with all samples in order to determine the specificity of the interaction. The dynamic response (DR) was deduced from fluorescence relaxation measurements of the switching nanolevers present on all the 6 spots of the chip (reference and sample spots). The difference in motion rates between peptide-free DNA nanolevers and MCP-carrying nanolevers was expressed as relative $\triangle \mathrm{DR}$ (in \%). All curves were analysed by nonlinear fitting of single-exponential functions with the switchANALYSIS ${ }^{\oplus}$ software from Dynamic Biosensors. The error presented with the results corresponds to the global fit error of all measurements.

\section{Metal-chelation test}

The global chelation capacity of hydrolysates was determined upon $\mathrm{Cu}^{2+}$ chelation by spectrophotometry using murexide as colour indicator. This test was carried out as described in several studies. ${ }^{24,32,33}$ Hydrolysates were prepared at different concentrations varying between 2 and $40 \mathrm{~g} \cdot \mathrm{L}^{-1}$ also expressed in $\mathrm{mM}$ eq. $\mathrm{NH}_{2}$. EDTA and carnosine were both used as positive controls for metal chelation and prepared in a range of $0.4-40 \mathrm{mM}$. EDTA, carnosine and hydrolysate solutions were directly diluted in a microplate with hexamine buffer for a total volume of $143 \mu \mathrm{L}$. Then, $143 \mu \mathrm{L}$ of a $3 \mathrm{mM} \mathrm{CuSO}_{4}$ in hexamine buffer and $14 \mu \mathrm{L}$ of $1 \mathrm{mM}$ murexide solution were added in each well (total volume: 300 $\mu \mathrm{L})$. The 96-well plate was incubated for $3 \mathrm{~min}$ at room temperature and the absorbance was read at two wavelengths, i.e. $485 \mathrm{~nm}$ and $520 \mathrm{~nm}$, for the copper-murexide complex and the murexide alone, respectively. The $A_{485} / A_{520}$ ratio was considered as proportional to the free copper ion $\left(\mathrm{Cu}^{2+}\right)$ concentration. 
$\mathrm{Cu}^{2+}$ complexation $(\%)=\frac{\left[\left(\mathrm{A}_{485} / \mathrm{A}_{520}\right)_{0}-\left(\mathrm{A}_{485} / \mathrm{A}_{520}\right)_{\mathrm{s}}\right]}{\left(\mathrm{A}_{485} / \mathrm{A}_{520}\right)_{0}} \times 100$

With $\left(\mathrm{A}_{485} / \mathrm{A}_{520}\right)_{0}=$ ratio of absorbances measured in the absence of sample, and $\left(A_{485} / A_{520}\right)_{s}=$ ratio of absorbances measured in the presence of sample (EDTA, carnosine or hydrolysate).

\section{Results and Discussion}

\section{SwitchSENSE ${ }^{\circledR}$ measurements with model peptides}

As a starting point, static and dynamic measurements of switchSENSE ${ }^{\circledR}$ were performed with synthetic peptides having 2-6 residues in order to test if this new emerging biosensing technology was sensitive enough to detect the binding of small-sized MCPs. Carnosine, $\mathrm{HHHHHH}, \mathrm{HHH}, \mathrm{HW}$ and $\mathrm{HGH}$ are known to chelate transition metals due to the presence of histidine residues. ${ }^{34}$

Static measurement for fluorescence proximity sensing is a real-time measurement of kinetics responding to changes to the molecular environment upon analyte binding. The fluorescence is partly quenched when the analyte binds to nickel ions (association), which is close to the fluorescent probe while it increases if the analyte is released (dissociation). The real-time molecular interaction kinetics are shown in Figure 1. As observed for all the samples, the measured fluorescence signal has always decreased (fluorescence quenching), highlighting an association of the peptides on the immobilized nickel ions. However, the dissociation phase was not observed for the investigated synthetic peptides. This can be explained by their high affinity for nickel ions (three nickel ions are immobilized per DNA nanolever) leading to a very slow dissociation that cannot be observed within the two hours of the dissociation phase measurement. The observed rate constant (kobs) determined for carnosine, $\mathrm{HHHHHH}, \mathrm{HW}, \mathrm{HGH}$ and $\mathrm{HHH}$ according to the data depicted 
in Figure 1 are summarized in Table 1. The results showed no significant variation in the kobs values as a function of peptide concentrations, suggesting that saturation has been reached with the peptide concentrations $\left(K_{\mathrm{D}}<0.5 \mu \mathrm{M}\right)$ used. Due to the low signal intensity, it is not possible to use lower concentrations of peptides. Therefore, the values of the equilibrium constants of association and dissociation ( $K_{\mathrm{A}}$ and $\left.K_{\mathrm{D}}\right)$ cannot be determined. In addition, comparison of the association kobs values at a defined peptide concentration could give information on the relative association rate. Consequently, and according to Table 1, the fastest observed association rate is obtained with $\mathrm{HHHHHH}$, then with the di- and tri-peptides and finally with carnosine.

In order to find a more sensitive approach, the effect of bounded peptides on molecular motion of the nanolevers was studied by carrying out experiments in dynamic mode. To that purpose, the up-to-down motion of the nanolevers was tracked in real time through fluorescence measurement. Upon binding of an analyte (MCP herein), the hydrodynamic friction and the subsequent motion of the nanolevers are in theory both affected. The dynamic response (DR) decreases when an analyte (peptide herein) binds to the immobilized ligand (nickel ions in the present study). The strategy used is explained on Figure 2. First, T40 buffer (see Materials and Methods) was injected through the microfluidic of the biochip and the DR of the reference electrodes E1 and E2 (in the absence of $\mathrm{Ni}^{2+}$ immobilized) and of the sample electrodes $\mathrm{E} 3$ to $\mathrm{E} 6$ (in the presence of $\mathrm{Ni}^{2+}$ immobilized) were determined. Secondly, peptide samples were loaded and the DR was determined.

Thus, the five synthetic peptides (10 $\mu \mathrm{M}$ in T40 buffer) were investigated by the molecular dynamic mode. The differences of dynamic response between control (i.e. peptide-free buffer) and investigated synthetic peptides, defined as $\Delta \mathrm{DR}$, are depicted in Figure 3. The 
conformational study displays poor sensitivity for low-molecular weight and small-sized peptides (2 or 3 amino-acid residues) probably because the molecular friction was not sufficiently slowed down by the binding of such small-sized materials onto the nanolevers. However, it was possible to unveil weak response for $\mathrm{HHH}$, which marked the sensitivity limit of the dynamic mode, while the hexapeptide $\mathrm{HHHHHH}$ led to a strong dynamic response.

Therefore, these results show that switchSENSE ${ }^{\circledR}$ technology is applicable on small synthetic MCPs and that the two modes can give different information, as the static mode is size-independent but not very sensitive for high affinity MCP-Ni ${ }^{2+}$ association, whereas the dynamic mode seems to have restrictions for very low molecular weight peptides but is much sensitive with peptides able to alter the motion of the nanolevers.

\section{Metal-chelation capacity of Tilapia viscera and soy proteins hydrolysates}

Based on their protein composition, and in particular in histidyl residues usually involved in metal ions chelation, soy and Tilapia viscera protein hydrolysates were selected for this study. Indeed, in the soy protein isolate, $\beta$-conglycinin 7S (30 His; UniProtKB accession numbers P11827 and P25974) and glycinin G5 (5 His; P04347) represent $80 \%$ of the total protein. ${ }^{35,36}$ In TPH, histidine was found at a concentration of $12 \mathrm{mg} / \mathrm{g}$ of protein. ${ }^{31}$ Besides, the chelating activity may also be influenced by the presence of negatively charged amino acids, present in $63 \mathrm{mg} / \mathrm{g}$ of protein in $\mathrm{TPH} .{ }^{31,37}$

Many studies have extracted and screened metal-chelating peptides after similar enzymatic hydrolysis for soy and tilapia proteins. ${ }^{38,39}$ Alcalase ${ }^{\circledR}$, Protamex ${ }^{\circledR}$ and 
Flavourzyme $^{\circledR}$ enzymes are widely listed in literature for producing antioxidant hydrolysates with their hydrolysing optimum conditions. ${ }^{40}$

Prior to launching switchSENSE ${ }^{\circledR}$ measurements, the ability of TPH and SPH to bind copper ion was investigated by UV-visible spectrophotometry. It is noteworthy to mention that despite the difference in metal ion used, $\mathrm{Ni}^{2+}$ in switchSENSE ${ }^{\circledR}$ or $\mathrm{Cu}^{2+}$ in spectrophotometry, these two metal ions have similar metal chelation properties in regards to the HSAB theory. Indeed, both belong to the intermediate acids according to the HSAB theory and are able to deprotonate the peptide's amide functions, and induce metal coordination. ${ }^{41}$ Figure 4, Panel $\mathbf{A}$, presents the $\mathrm{Cu}^{2+}$ chelation capacity as a function of molar ratio ( $\mathrm{mM}$ eq. $\mathrm{NH}_{2}$ of hydrolysate $/ \mathrm{mM} \mathrm{CuSO}_{4}$ ). Saturation was observed for all hydrolysates, showing the presence of peptides with affinity for copper. Moreover, a quantitative method previously developed in our group was applied in order to compare $\mathrm{M}^{2+}$ chelation capacities between hydrolysates. ${ }^{24}$ Two indices, EDTA Equivalent Chelating Capacity (EECC) and Carnosine Equivalent Chelating Capacity (CECC) were calculated from the slopes of the linear parts of the $\mathrm{Cu}^{2+}$ chelation graphs of SPH, EDTA and carnosine (Figure 4, Panels A \& B), where:

$\mathrm{EECC}=($ slope $) \mathrm{H} /(\text { slope })_{\text {EDTA }}$

$\mathrm{CECC}=($ slope $) \mathrm{H} /(\text { slope })_{\text {carnosine }}$

The EECC and CECC values were calculated for all hydrolysates ( $\mathrm{H}$ is either TPH or SPH) and presented in Table 2. From this latter, TPH is clearly the best preparation in terms of copper chelation activity. Concerning SPHs, a limited hydrolysis time $(1 \mathrm{~h})$ is sufficient to reveal metal chelation activity. Besides, the SPH obtained with Flavourzyme ${ }^{\circledR}$ is largely better in terms of chelation capacity than the two other SPHs although hydrolysis by 
Flavourzyme ${ }^{\circledR}$ is not completed. Note that the hydrolysis with Alcalase ${ }^{\circledR}$ and Protamex ${ }^{\circledR}$ were more extensive as shown by SDS-PAGE analysis (Figure S5). Therefore, the metalchelation test validates the presence of MCPs in all investigated hydrolysates.

\section{SwitchSENSE ${ }^{\circledR}$ measurements for screening MCPs in hydrolysates}

To check if the switchSENSE ${ }^{\circledR}$ technology is sensitive enough to detect MCPs present in a complex mixture of peptides, the static and the dynamic fluorescent measurements were applied to SPHs (1 h hydrolysis) and TPH.

The static measurements carried out on all the hydrolysates showed that they display a specific interaction with nickel ions, except the SPH obtained by Flavourzyme ${ }^{\circledR}$ treatment, even at its highest concentration of $1 \mathrm{mM}$ eq. $\mathrm{NH}_{2}$ (Figure 5A). This result suggests that MCP concentration in this latter hydrolysate is lower than in the two other SPHs, as shown by the low yield of hydrolysis of this sample (Figure S5). In addition, the observed rate constants $\left(k_{o b s}\right)$ determined for the two other SPHs (obtained by Alcalase ${ }^{\circledR}$ and Protamex ${ }^{\circledR}$ ) were largely slower than kobs determined for TPH (Table 1). Indeed, a minimal concentration of $100 \mu \mathrm{M}$ eq. $\mathrm{NH}_{2}$ of each kind of $\mathrm{SPH}$ was required to allow the determination of a kobs value with accuracy whereas $5 \mu \mathrm{M}$ is sufficient for TPH (Table 1). These results evidence the presence of MCPs able to bind nickel ions specifically, at least in 3 of 4 investigated hydrolysates.

When the dynamic mode was applied for the 4 hydrolysates, no or almost no peptides were stuck onto the DNA nanolevers, showing that there is no unspecific binding also with complex mixtures (reference electrodes E1 and E2) (Figure 5B). However, it was difficult to determine any change in the motion of the DNA nanolevers with TPH. Based on the 
size distribution chromatographic analysis carried out on $\mathrm{TPH},{ }^{30}$ this can be due to the presence of a majority of small size peptides (di- and tri-peptides). On the other hand, a great change of the molecular friction of the DNA nanolevers was observed for all SPHs. Especially, the hydrolysate produced with Flavourzyme ${ }^{\circledR}$ displayed the most important decrease in motion, probably due to the presence of longer-sized peptides.

Altogether, it is interesting to note that the presence of small MCPs in TPH is only detectable with the static mode, whereas long MCPs present in SPH produced with Flavourzyme ${ }^{\circledR}$ are only revealed with the dynamic mode. Thus, switchSENSE ${ }^{\circledR}$ technology is relevant to screen MCPs in complex mixtures of peptides such as hydrolysates. As already observed for the synthetic peptides, the static and dynamic modes give different but complementary pieces of information. Static mode is relevant for high concentration and small peptides, whereas dynamic mode is more sensitive for longer peptides. Tilapia viscera as well as soy isolates were good sources of MCPs and therefore, their byproducts might be studied for their putative biological properties, related especially to their antioxidant properties. For the future, Immobilized Metal ion Affinity Chromatography (IMAC) coupled to mass spectrometry experiments will be performed on-line in order to isolate and to identify some MCPs present in these hydrolysates and that possess potential interesting antioxidant properties.

\section{List of abbreviations}

IMAC: Immobilized Metal lon Affinity Chromatography

MCP: Metal-Chelating Peptides

NTA: NitriloTriacetic Acid 
PBS: Phosphate-Buffered Saline

T40: $\mathrm{NaCl} 40 \mathrm{mM}$-containing Tris Buffer

SDS-PAGE: Sodium Dodecyl Sulfate Polyacrylamide Gel Electrophoresis

SPH: Soy Protein Hydrolysate

SPR: Surface Plasmon Resonance

TPH: Tilapia Protein Hydrolysate

\section{Acknowledgments}

The authors acknowledge financial support from the "Impact Biomolecules" project of the "Lorraine Université d'Excellence" (in the context of the "Investissements d'avenir" program implemented by the French National Research Agency - ANR project number 15-004). The authors would like also to thank the financial support of Institut Carnot ICEEL (Project 2019, MELISSA ICEEL INTRA). The switchSENSE ${ }^{\circledR}$ technology is available on the ASIA platform (University of Lorraine; https://a2f.univ-lorraine.fr/en/asia-2/).

\section{Supporting information}

Preparations for TPH and SPH (S1 \& S2, respectively) and their peptide quantification by OPA dosage (Table S1). Molecular structure of model peptides (S3). The principle of switchSENSE ${ }^{\circledR}$ (S4). SDS-PAGE for SPHs (S5).

\section{References}

(1) El hajj, S.; Sepúlveda-Rincon, T.; Paris, C.; Giraud, T.; Csire, G.; Stefan, L.; Selmeczi, K.; Girardet, J. M.; Desobry, S.; Bouhallab, S.; Muhr, L.; Gaucher, C.; CanabadyRochelle, L. Application in nutrition: Mineral-binding. Toldra, F.; Wu, J. (ed.) 
Biologically active peptides. Chapter 19 in press. Publication in June 2021. https://www.elsevier.com/books/biologically-active-peptides/toldra/978-0-12821389-6

(2) Megías, C.; Pedroche, J.; Yust, M. M.; Girón-Calle, J.; Alaiz, M.; Millán, F.; Vioque, J. Affinity purification of copper-chelating peptides from sunflower protein hydrolysates. J. Agric. Food Chem. 2007, 55, 6509-6514.

(3) Canabady-Rochelle, L.; Harscoat-Schiavo, C.; Kessler, V.; Fournier, F.; Girardet J. M. Determination of reducing power and chelating ability of antioxidant peptides: Revisited Methods. Food Chem. 2015, 183, 129-135.

(4) Yousef, E. N.; Sesham, R.; McCabe, J. W.; Vangala, R.; Angel, L. A. Ion Mobility-Mass Spectrometry Techniques for Determining the Structure and Mechanisms of Metal Ion Recognition and Redox Activity of Metal Binding Oligopeptides. J. Vis. Exp. 2019 (151), 1-14.

(5) Guo, L.; Harnedy, P. A.; Li, B.; Hou, H.; Zhang, Z.; Zhao, X.; FitzGerald, R. J. Food protein-derived chelating peptides: Biofunctional ingredients for dietary mineral bioavailability enhancement. Trends Food Sci. Technol. 2014, 37, 92-105.

(6) Ma, X.; Liu, C.; Song, W.; Che, S.; Wang, C.; Feng, X.; Li, B.; Dai, Y. Evaluating the efficacy of a ferrous-ion-chelating peptide from Alaska pollock frame for the improvement of iron nutritional status in rats. Food Funct. 2019, 10, 4888-4896.

(7) Chen, H. M.; Muramoto, K.; Yamauchi, F.; Fujimoto, K.; Nokihara, K. Antioxidative properties of histidine-containing peptides designed from peptide fragments found in the digests of a soybean protein. J. Agric. Food Chem. 1998, 46, 49-53.

(8) Bamdad, F.; Chen L. Antioxidant capacity of fractionated barley hordein hydrolysates in relation to peptide structure. Mol. Nutr. Food Res. 2013, 57: 493-503. 
(9) Peng, X.; Kong, B.; Xia, X.; Liu, Q. Reducing and radical-scavenging activities of whey protein hydrolysates prepared with Alcalase. Int. Dairy J. 2010, 20, 360-36.

(10) Food and Agriculture Organization of the United Nations. The state of world fisheries and aquaculture 2018- Meeting the sustainable development goals. 2018, Rome.

(11) Robert, M.; Zatylny-Gaudin, C.; Fournier, V.; Corre, E.; Le Corguillé, G.; Bernay, B.; Henry, J. Molecular characterization of peptide fractions of a Tilapia (Oreochromis niloticus) by-product hydrolysate and in vitro evaluation of antibacterial activity. Process Biochem. 2015, 50, 487-492.

(12) Gómez, L.J.; Gómez, N.A.; Zapata, J.E.; López-García, G.; Cilla, A.; and Alegría, A. Optimization of the Red Tilapia (Oreochromis spp.) Viscera Hydrolysis for Obtaining Iron-Binding Peptides and Evaluation of In Vitro Iron Bioavailability. Foods 2020, 9, 883.

(13) Sierra, L.; Fan, H.; Zapata, J.; and Wu, J. Antioxidant peptides derived from hydrolysates of red tilapia (Oreochromis sp.) scale. LWT 2021, 146, 111631.

(14) Zhang, S.B.; Wang, Z.; and Xu, S.Y. Optimization of the Aqueous Enzymatic Extraction of Rapeseed Oil and Protein Hydrolysates. J. Am. Oil Chem. Soc. 2021, 84, 97-105.

(15) Ashaolu, T. J. Applications of soy protein hydrolysates in the emerging functional foods: a review. Int. J. Food Sci. Technol. 2020, 55, 421-428.

(16) Alhazmi, H. A.; Nachbar, M.; Albishri, H.M.; Abd El-Hady, D.; Redweik, S.; El Deeb, S.; Watzig, H. A comprehensive platform to investigate protein-metal ion interactions by affinity capillary electrophoresis. J. Pharm. Biomed. Anal. 2015, 107, 311-317.

(17) Helfferich, F. Ligand exchange: a novel separation technique. Nature 1961, 189, 1001-1002. 
(18) Weinberger, S. R.; Morris, T. S.; Pawlak, M. Recent trends in protein biochip technology. Pharmacogenomics 2000, 1, 395-416.

(19) Paris, C.; Selmeczi, K.; Ebel, B.; Stefan, L.; Csire, G.; Cakir-Kiefer, C.; Desobry, S.; Canabady-Rochelle, L.; Chaimbault, P. Metabolomics approach based on LC-HRMS for the fast screening of iron(II)-chelating peptides in protein hydrolysates. Anal. Bioanal. Chem. 2021, 413, $315-329$

(20) Nieba, L.; Nieba-Axmann, S. E.; Persson, A.; Hämäläinen, M.; Edebratt, F.; Hansson, A.; Lidholm, J.; Magnusson, K.; Karlsson, A. F.; Plückthun, A. BIACORE analysis of histidine-tagged proteins using a chelating NTA sensor chip. Anal. Biochem. 1997, 252, 217-228.

(21) Bernaudat, F.; Bülow, L. Rapid evaluation of nickel binding properties of his-tagged lactate dehydrogenases using surface plasmon resonance. J. Chromatogr. A 2005, 1066, 219-224.

(22) Kurzatkowska, K.; Mielecki, M.; Grzelak, K.; Verwilst, P.; Dehaen, W.; Radecki, J.; Radecka, H. Immobilization of His-tagged kinase JAK2 onto the surface of a plasmon resonance gold disc modified with different copper (II) complexes. Talanta 2014 130, $336-341$.

(23) Knecht, S.; Ricklin, S.; Eberle, A.; Ernst, B. Oligohis-tags: mechanisms of binding to $\mathrm{Ni}^{2+}-\mathrm{NTA}$ surfaces. J. Mol. Recognit. 2009, 22, 270-279.

(24) Canabady-Rochelle, L.; Selmeczi K.; Collin S.; Pacs A.; Muhr L.; Boschi-Muller S. SPR Screening of metal chelating peptides in a hydrolysate for their Antioxidant Properties. Food Chem. 2018, 239, 478-485. 
(25) Muhr, L.; Pontvianne, S.; Selmeczi, K.; Paris, C.; Boschi-Muller, S.; CanabadyRochelle, L. Chromatographic separation simulation of metal-chelating peptides from surface plasmon resonance. J. Sep. Sci. 2020, 43, 2014-2247.

(26) Langer, A.; Hampel, P. A.; Kaiser, W.; Knezevic, J.; Welte, T.; Villa, V.; Maruyama, V.; Svejda, M.; Jähner, S.; Fischer, F.; Strasser, R.; Rant, U. Protein analysis by timeresolved measurements with an electro-switchable DNA chip. Nat. Commun. 2013, 4, 2099.

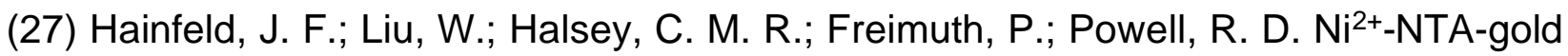
clusters target His-tagged proteins. J. Struct. Biol. 1999, 127, 185-198.

(28) Sepúlveda, C. T.; Zapata, J. E. Effects of Enzymatic Hydrolysis Conditions on the Antioxidant Activity of Red Tilapia (Oreochromis spp.) Viscera Hydrolysates. Curr. Pharm. Biotechnol. 2020, 20, 1249-1258.

(29) Frister, H.; Meisel, H.; Schlimme, E. OPA method modified by use of N,N-dimethyl2-mercaptoethylammonium chloride as thiol component. Fresenius J. Anal. Chem. 1988, 330, 631-633.

(30) Laemmli, U.K.; Favre, M. Maturation of the head of bacteriophage T4. I. DNA packaging events. J. Mol. Biol. 1973, 80, 575-599.

(31) Sepúlveda, C. T.; Zapata, J. E.; Martínez-Álvarez, O.; Alemán,A.; Montero, M. P.; Gómez-Guillén, M. C. The Preferential Use of a Soy-Rapeseed Lecithin Blend for the Liposomal Encapsulation of a Tilapia Viscera Hydrolysate. LWT-Food Sci. Technol. 2020, 110530.

(32) Wu, H. C.; Shiau, C. Y.; Chen, H. M.; Chiou, T. K. (2003). Antioxidant Activities of Carnosine, Anserine, Some Free Amino Acids and Their Combination. J. Food Drug Anal. 2003, 11, 148-53. 
(33) Wong, S.; Leong, L.; Williamkoh, J. Antioxidant Activities of Aqueous Extracts of Selected Plants. Food Chem. 2006, 99, 775-83.

(34) Willett, W. S.; Gillmor, S. A.; Perona, J. J.; Fletterick, R. J.; Craik, C. S. Engineered Metal Regulation of Trypsin Specificity. Biochemistry 1995, 34, 2172-2180.

(35) Adachi, M.; Kanamori, J.; Masuda, T.; Yagasaki, K.; Kitamura, K.; Mikami, B.; Utsumi, S. Crystal structure of soybean 11S globulin: glycinin A3B4 homohexamer. PNAS USA 2003, 100, 7395-7400.

(36) Nishinari, K.; Fang, Y.; Guo, S.; Phillips, G. O. Soy proteins: A review on composition, aggregation and emulsification. Food Hydrocoll. 2014, 39, 301-318.

(37) Zhang, Y.; Duan, X.; Zhuang, Y. Purification and characterization of novel antioxidant peptides from enzymatic hydrolysates of tilapia (Oreochromis niloticus) skin gelatin. Peptides 2012, 38, 13-21.

(38) Zhang, Q.; Tong, X.; Qi, B.; Wang, Z.; Li, Y.; Sui, X.; Jiang, L. Changes in antioxidant activity of Alcalase-hydrolyzed soybean hydrolysate under simulated gastrointestinal digestion and transepithelial transport. J. Funct. Foods 2018, 42, $298-305$.

(39) Charoenphun, N.; Cheirsilp, B.; Sirinupong, N.; Youravong, W. Calcium-binding peptides derived from tilapia (Oreochromis niloticus) protein hydrolysate. Eur. Food Res. Technol. 2013, 236, $57-63$.

(40) Korhonen, H.; Pihlanto, A. Bioactive peptides: Production and functionality. Int. Dairy J. 2006, 16, $945-960$.

(41) Sóvágó, I.; Ősz, K. Metal ion selectivity of oligopeptides. Dalton Trans. 2006, 23841- 
3854. 


\section{Captions to Figures}

Figure 1. Association kinetics analysis of synthetic peptides onto immobilized nickel ions by using the switchSENSE ${ }^{\circledR}$ technology. Raw data are superimposed by global exponential fits for various concentrations of each peptide. A blank control performed with T40 buffer instead of analyte was subtracted to normalize the signal. The kobs were determined for each kinetics measurement. Fnorm, normalized fluorescence.

Figure 2. Real-time switchSENSE ${ }^{\circledR}$ analysis of molecular interaction between the investigated analyte (synthetic peptides or hydrolysates (TPH, SPHs)) and nickel ions immobilized on DNA nanolevers attached to the gold surface of the chip. The chip is composed of six switchable electrodes, all in contact with the running buffer or analytes loaded into the microfluidic. In molecular dynamics mode, nanolevers are deliberately moved by way of alternating the voltage across the surface. The motion of the levers is tracked in real time. Upon analyte binding, the hydrodynamic friction of the nanolevers and their movement are affected. (A) Reference electrodes E1 and E2 in the presence of T40 buffer, (B) Sample electrodes E3 to E6 in the presence of T40 buffer, (C) Reference electrodes in the presence of analyte (i.e. synthetic peptides or hydrolysates), (D) Sample electrodes in the presence of analyte.

Figure 3. Molecular dynamics experiments performed by switchSENSE ${ }^{\circledR}$ technology with 
synthetic peptides. Experiments were performed in T40 buffer, then in the presence of sample (at $10 \mu \mathrm{M}$ ). Nanolevers' motions were expressed as dynamic response (DR). The relative difference $\Delta \mathrm{DR}$ (in \%) was calculated from the various motions determined in the presence and in the absence of sample. Unspecific binding onto the DNA double strands was determined from the $\Delta \mathrm{DR}$ of the reference electrodes E1 and E2 free of nickel, whereas specific interaction with nickel was determined from the $\Delta \mathrm{DR}$ of the sample electrodes E3 to E6.

Figure 4. Copper chelation capacity (\%) of the different hydrolysates (A), EDTA and carnosine (B) as a function of molar ratio $\left(\mathrm{mM}\right.$ eq $\mathrm{NH}_{2}$ of hydrolysate or $\mathrm{mM}$ EDTA, carnosine/ $\mathrm{mM} \mathrm{CuSO}_{4}$ ). SPHs were prepared by Alcalase ${ }^{\circledR}$, Protamex $^{\circledR}$, or Flavourzyme ${ }^{\circledR}$ one- or three-hour treatment. The TPH was prepared by Alcalase ${ }^{\circledR}$ three-hours treatment.

Figure 5. Association kinetics analysis (A) and Molecular dynamics experiments (B) of SPHs and TPH onto immobilized nickel ions by using the switchSENSE ${ }^{\circledR}$ technology. The SPHs were prepared by Alcalase $^{\circledR}$, Protamex ${ }^{\circledR}$, or Flavourzyme ${ }^{\circledR}$ one-hour treatment. The TPH was prepared by Alcalase ${ }^{\circledR}$ threehours treatment. The kinetics raw data are superimposed by global exponential fits for various concentrations of each analyte. The kobs were determined for each kinetics measurement. Fnorm, normalized fluorescence. For the motion determination, experiments were performed in T40 buffer, then in the presence 
of sample (SPH at $1000 \mu \mathrm{M}$ eq. $\mathrm{NH}_{2}$ \& $\mathrm{TPH}$ at $100 \mu \mathrm{M}$ eq. $\mathrm{NH}_{2}$ ) and the nanolevers' motions were expressed as dynamic response (DR). The relative difference $\Delta \mathrm{DR}$ (in \%) was calculated from the various motions determined in the presence and in the absence of sample. Unspecific binding onto the DNA double strands was determined from the $\Delta \mathrm{DR}$ of the reference electrodes $\mathrm{E} 1$ and E2 free of nickel, whereas specific interaction with nickel was determined from the $\Delta \mathrm{DR}$ of the sample electrodes $\mathrm{E} 3$ to $\mathrm{E} 6$.

Table of Content. Screening Metal-Chelating Peptides in Hydrolysates using switchSENSE ${ }^{\circledR}$. 


\section{Tables}

Table 1. Observed rate constants (kobs) of synthetic peptides, SPHs and TPH association to immobilized nickel ions determined with the switchSENSE ${ }^{\circledR}$ method. Results are presented as mean \pm standard deviation.

\begin{tabular}{|c|c|c|}
\hline Sample & $\operatorname{kobs}\left(\mathbf{s}^{-1}\right)^{a}$ & $\operatorname{kobs}\left(\mathbf{s}^{-1}\right)^{b}$ \\
\hline Carnosine ( $\beta A H)$ & $0.013 \pm 0.001$ & $0.046 \pm 0.003$ \\
\hline НHНHНH & $0.140 \pm 0.015$ & $0.07 \pm 0.02$ \\
\hline HW & $0.095 \pm 0.008$ & $0.067 \pm 0.007$ \\
\hline $\mathrm{HGH}$ & $0.130 \pm 0.006$ & $0.085 \pm 0.010$ \\
\hline $\mathrm{HHH}$ & $0.10 \pm 0.02$ & $0.064 \pm 0.004$ \\
\hline SPH (Alcalase $\left.{ }^{\circledR} 1 \mathrm{~h}\right)$ & $0.09 \pm 0.01$ & $0.08 \pm 0.01$ \\
\hline SPH (Protamex $\left.{ }^{\circledR} 1 \mathrm{~h}\right)$ & $(1.1 \pm 0.9) \times 10^{-3}$ & $(1.0 \pm 0.2) \times 10^{-3}$ \\
\hline SPH (Flavourzyme ${ }^{\circledR} 1$ h) & not observed & not observed \\
\hline TPH (Alcalase ${ }^{\circledR} 3 \mathrm{~h}$ ) & $(1.9 \pm 0.2) \times 10^{-3}$ & $(29.5 \pm 5.4) \times 10^{-3}$ \\
\hline
\end{tabular}

${ }^{a} k_{\text {obs }}$ determined at $0.5 \mu \mathrm{M}$ for synthetic peptides, $5 \mu \mathrm{M}$ and $0.1 \mathrm{mM}$ eq. $\mathrm{NH}_{2}$ for TPH and $\mathrm{SPHs}$, respectively

${ }^{\mathrm{b}} k_{\mathrm{obs}}$ determined at $1 \mu \mathrm{M}$ for synthetic peptides, $10 \mu \mathrm{M}$ and $1 \mathrm{mM}$ eq. $\mathrm{NH}_{2}$ for $\mathrm{TPH}$ and SPHs, respectively 
Table 2. EECC and CECC values determined for TPH and SPHs

\begin{tabular}{|c|c|c|}
\hline & EECC $^{a}$ & CECC $^{b}$ \\
\hline EDTA & 1 & - \\
\hline Carnosine & - & 1 \\
\hline SPH (Alcalase $\left.{ }^{\circledR} 1 \mathrm{~h}\right)$ & 2.53 & 3.60 \\
\hline SPH (Alcalase $\left.{ }^{\circledR} 3 \mathrm{~h}\right)$ & 2.85 & 4.06 \\
\hline SPH (Protamex ${ }^{\circledR} 1$ h) & 4.51 & 6.41 \\
\hline SPH (Protamex ${ }^{\circledR} 3$ h) & 3.37 & 4.79 \\
\hline $\mathrm{SPH}^{C}\left(\right.$ Flavourzyme $\left.^{\circledR} \mathbf{1} \mathrm{h}\right)$ & 11.23 & 15.96 \\
\hline SPH (Flavourzyme ${ }^{\circledR} 3$ h) & 5.38 & 7.65 \\
\hline TPH (Alcalase ${ }^{\circledR} 3 \mathrm{~h}$ ) & 13.84 & 19.67 \\
\hline
\end{tabular}




\section{Figures}

Figure 1.
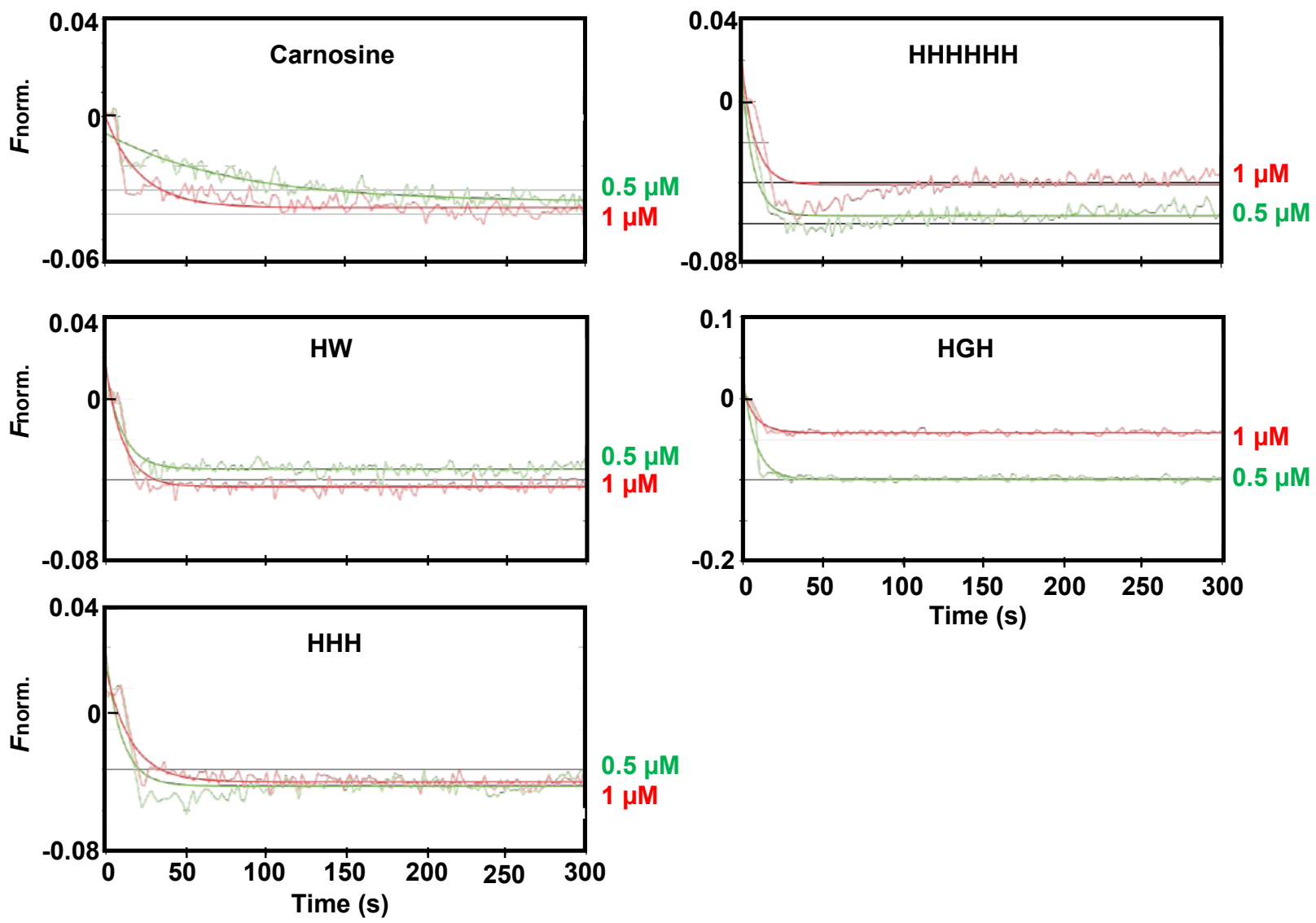


\section{Figure 2.}

A.

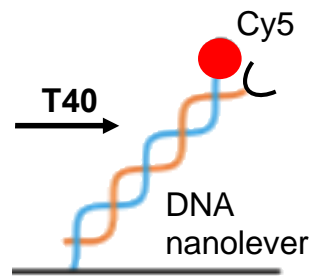

E1 and E2
B.

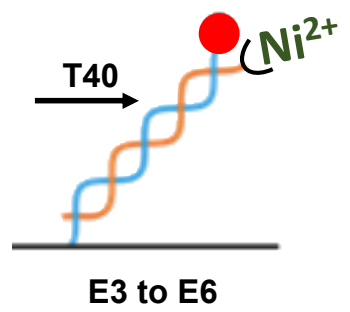

C.

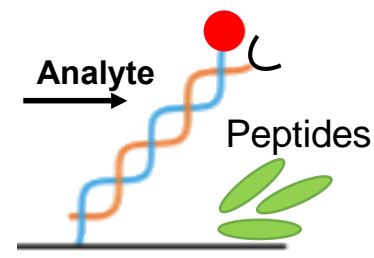

E1 and E2
D.

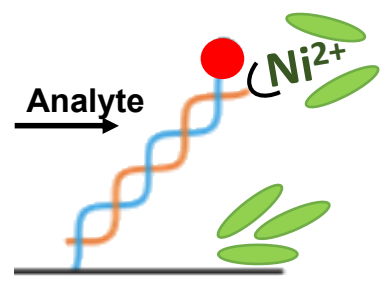

E3 to E6 
Figure 3.
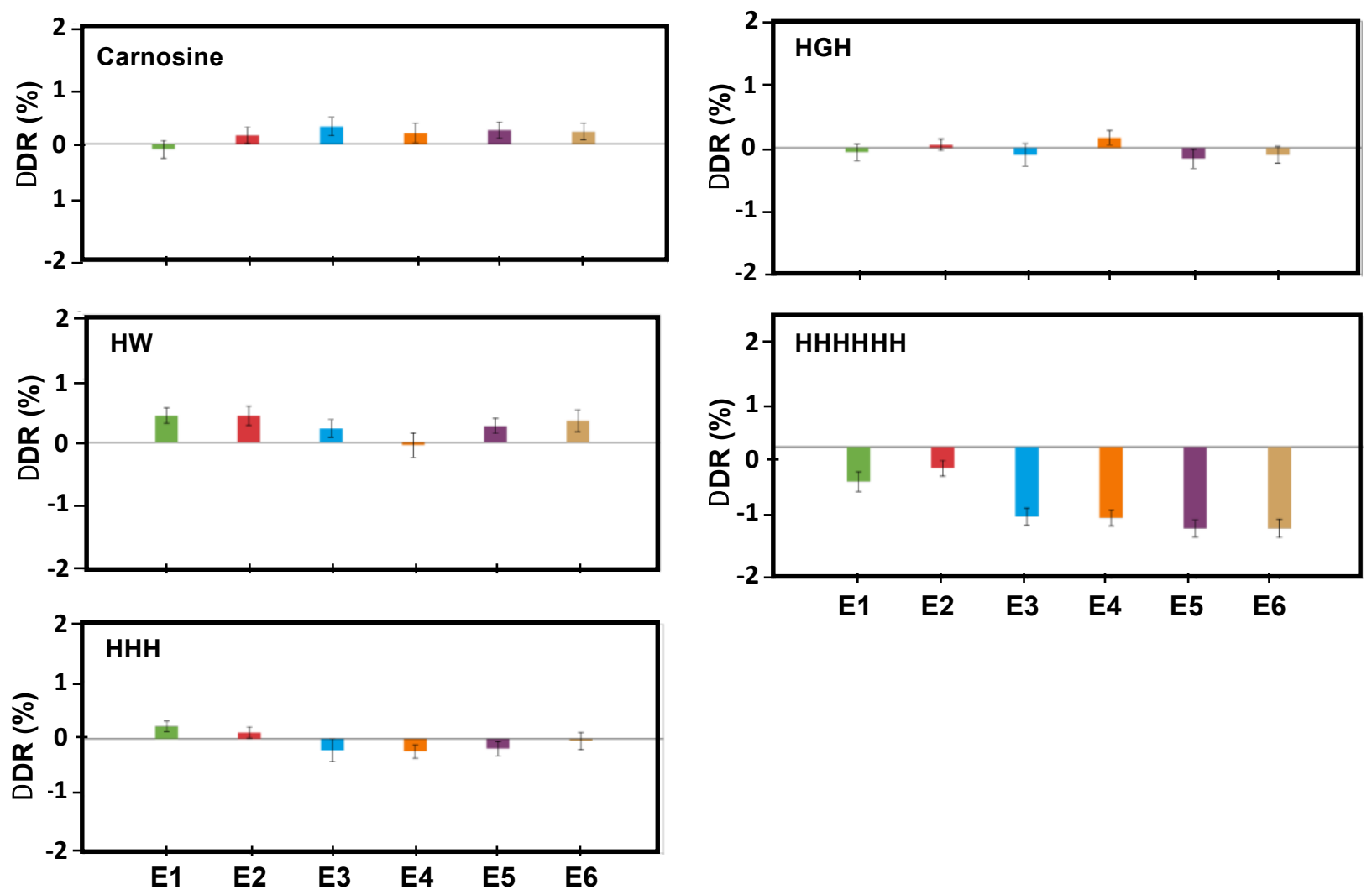
Figure 4.

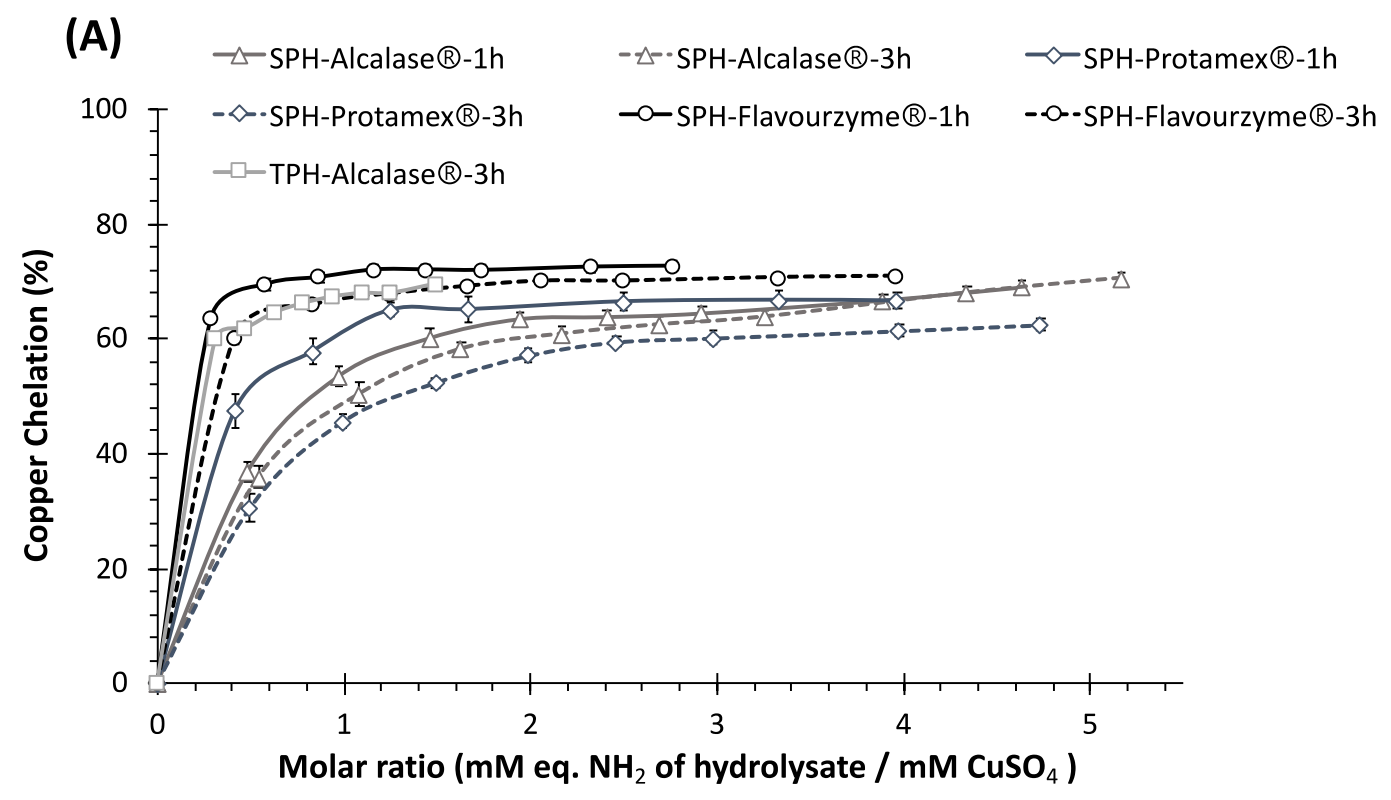

(B)

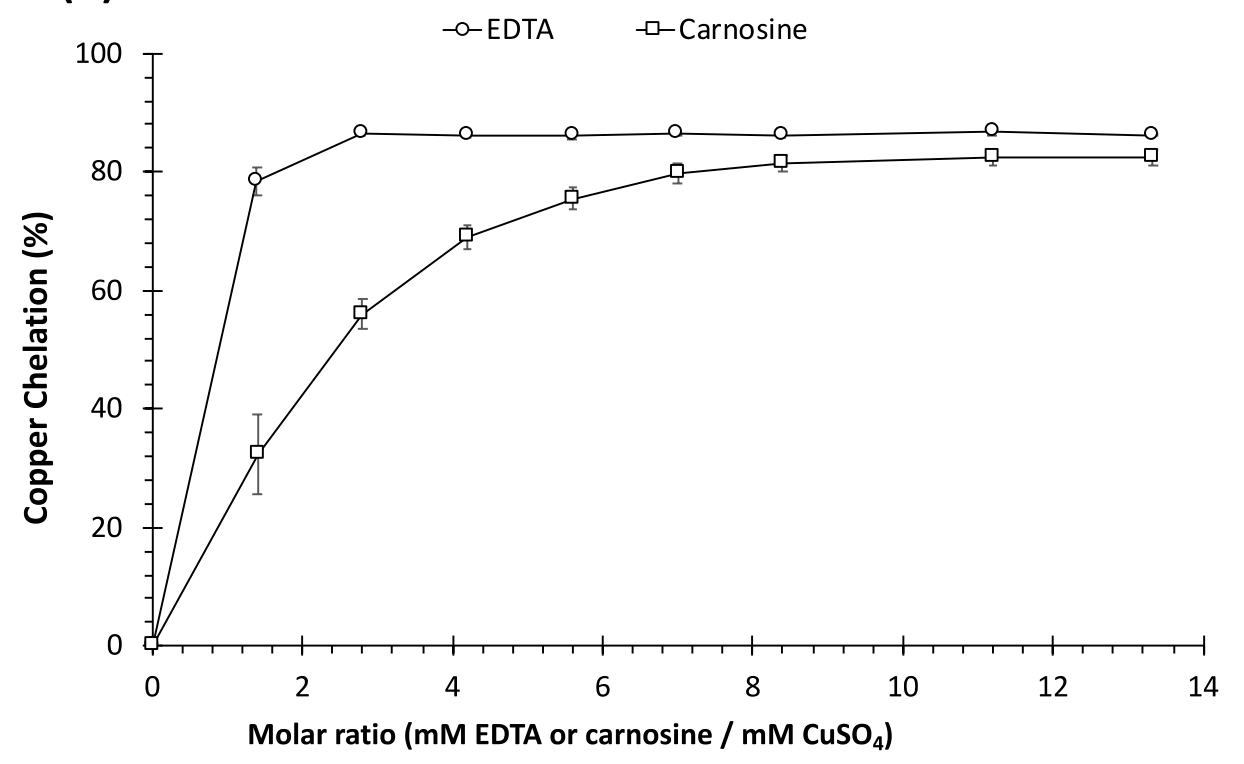


Figure 5.

A

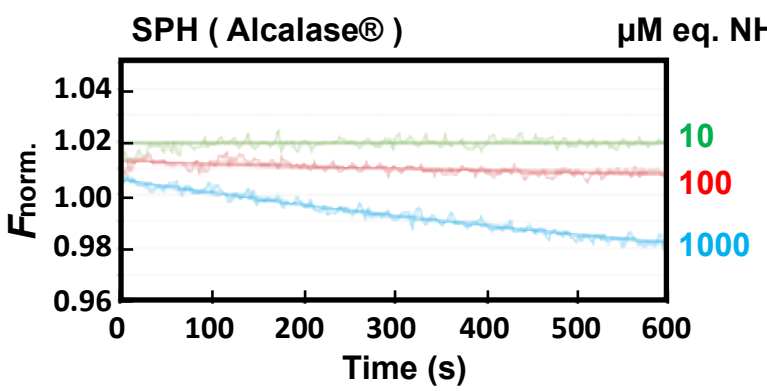

SPH ( Protamex®)

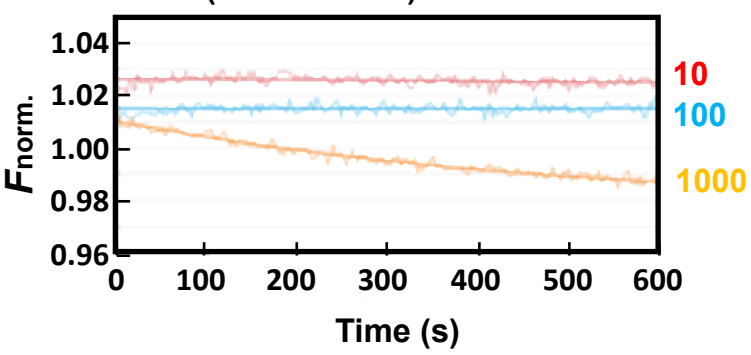

SPH ( Flavourzyme ${ }^{\circledR}$ )

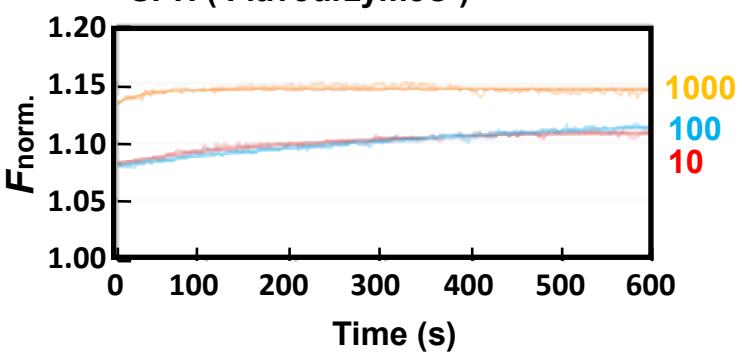

TPH ( Alcalase $®$ )

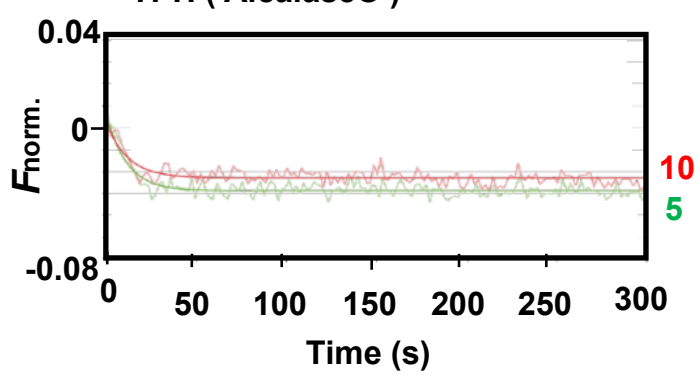

B

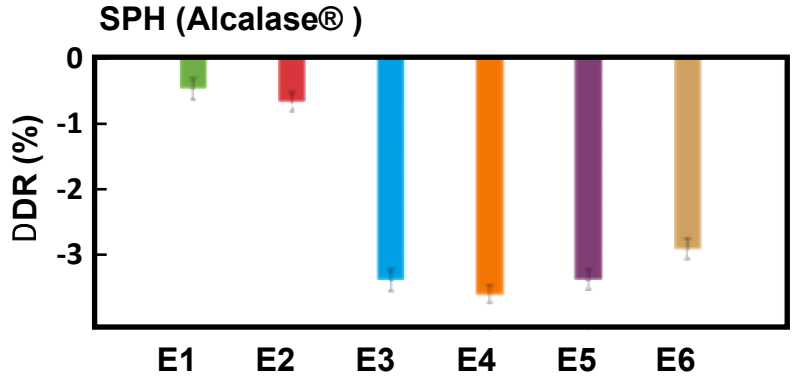

SPH (Protamex® )

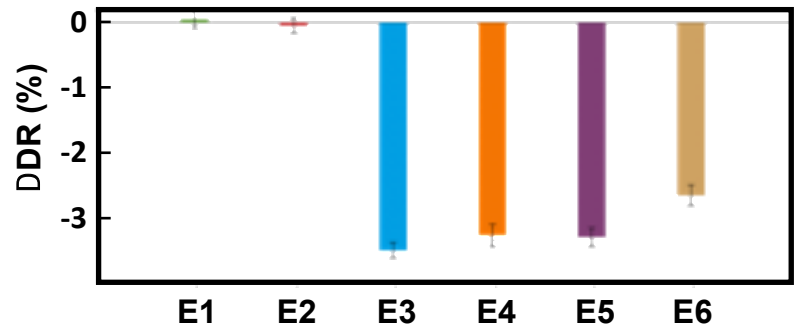

SPH ( Flavourzyme ${ }^{\circledR}$ )
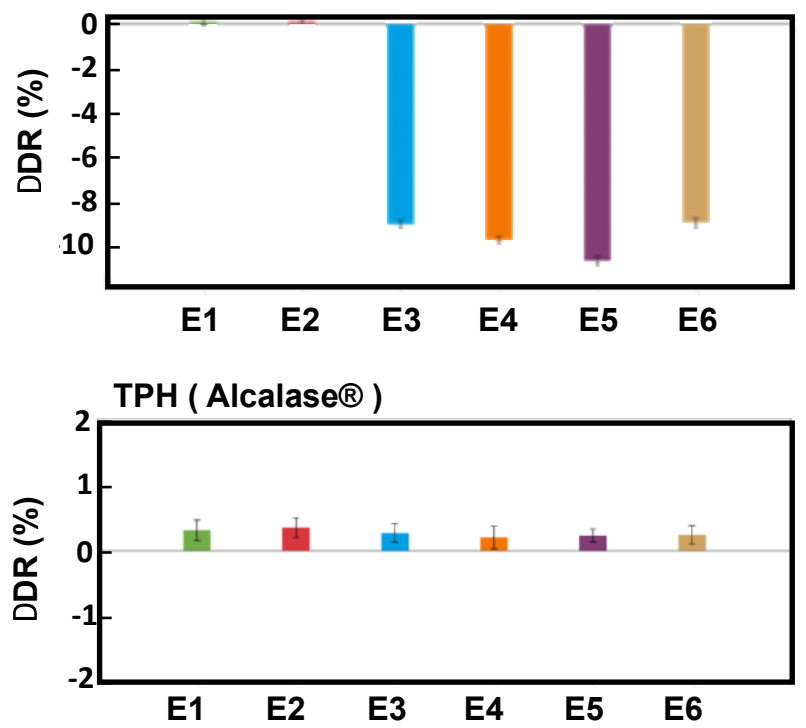


\section{Table of Content}

\section{Static mode}

Dynamic mode

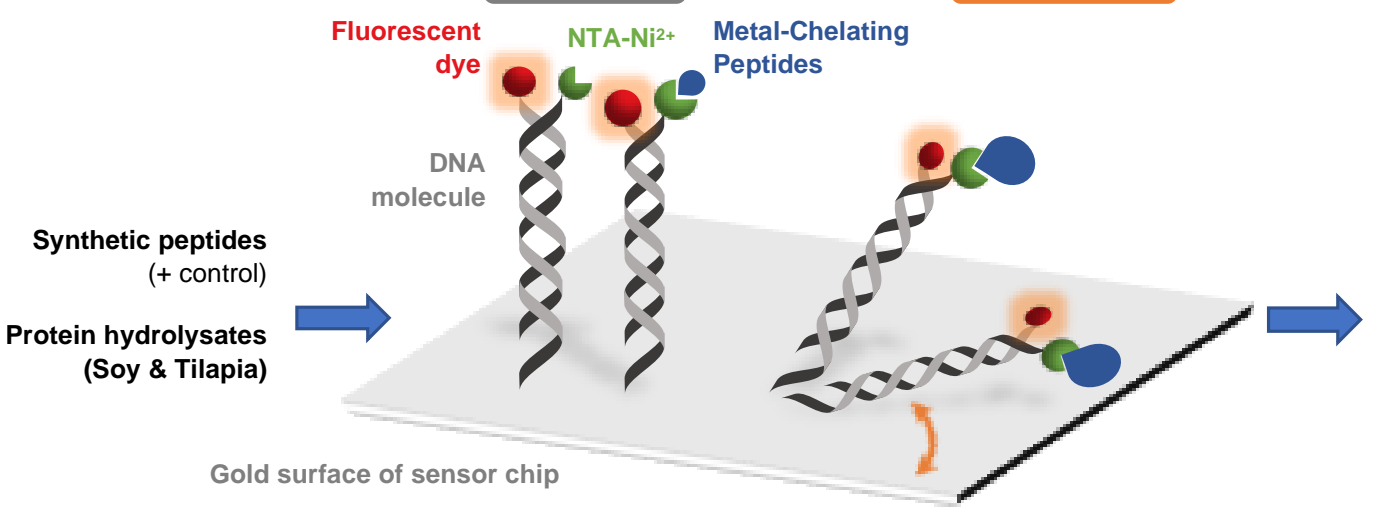

Sensitive method for MCPs screening in hydrolysates Static mode: for small-sized peptides Dynamic mode: for long-sized peptides 